\title{
Research on the Ecological Community of Mosses in Sygara Mountain of Tibet
}

\author{
Yulong Shi' ${ }^{1}$ Zhu Dong' ${ }^{1}$ Xiaotong Song², Heping Ma $^{{ }^{*}}$ \\ ${ }^{1}$ Research Institute of Plateau Ecology, Tibet Agriculture and Animal Husbandry College, Linzhi, China \\ ${ }^{2}$ College of Resource and Environmental, China Agricultural University, Beijing, China \\ Email: xz2016syl@sina.com, ^285477889@qq.com
}

How to cite this paper: Shi, Y.L., Dong, Z., Song, X.T. and Ma, H.P. (2017) Research on the Ecological Community of Mosses in Sygara Mountain of Tibet. Open Access Library Journal, 4: e3940.

https://doi.org/10.4236/oalib.1103940

Received: September 13, 2017

Accepted: October 28, 2017

Published: October 31, 2017

Copyright $\odot 2017$ by authors and Open Access Library Inc.

This work is licensed under the Creative Commons Attribution International License (CC BY 4.0).

http://creativecommons.org/licenses/by/4.0/

\begin{abstract}
In order to investigate the distribution of different ecological communities of Moss in Sygara Mountain of Tibet, we investigated the Mosses and analyzed them in laboratory during 2015 and 2016. The results showed that there were 28 families, 72 genera and 136 species, including Liverwort 3 families, 3 genera and 3 species, namely: Solenostoma obovatum (Ness) Schust, Hepat, Scapania gaochienia Fu ex T. Cao Acta Bot, Conocephalum conicum (L.) Dum. As the dominant families in the area, the order was Bryaceae, Dicranaceae, Pottiaceae, Brachytheciaceae, Grimmiaceae and Hypanaceae. The habitat was divided into 4 species community types: soil, stone, tree and aquatic community. The soil community was the main body among them, and the stone and tree community were subject, and the aquatic community was the lowest.
\end{abstract}

\section{Subject Areas \\ Environmental Sciences}

\section{Keywords}

Tibet, Sygara Mountain, Moss Community

\section{Physical Geography Overview}

Sygara Mountain $\left(93^{\circ} 12^{\prime}-95^{\circ} 35^{\prime} \mathrm{E}, 29^{\circ} 10^{\prime}-30^{\circ} 15^{\prime} \mathrm{N}\right)$, on the northwest side of Brahmaputra River in Southeast Tibet, at the intersection of the Nyainqntanglha Mountains and the Himalayas, in Nyingchi County, is the stretching branch of the Nyainqntanglha Mountains from northwest to southeast, forming a wide range of east-west slopes. The direction of the mountain is mainly northwest southeast, forming a larger range of east and west slope. Most of the area is above $3000 \mathrm{~m}$ above sea level, and the highest peak is $5300 \mathrm{~m}$ above sea level, 
and the lowest is located at the Dongpo palmer long cloth, about $2100 \mathrm{~m}$ above sea level. Affected by the Indian Ocean monsoon, the climate has the characteristics of winter and summer cool, dry and wet season. The average annual precipitation is $1134 \mathrm{~mm}$; the evaporation is $544.0 \mathrm{~mm}$; and the rainy season is from June to September, with the most concentrated in August, accounting for 30\% of the annual precipitation. The average annual temperature is $6.5^{\circ} \mathrm{C}$; the coldest monthly average temperature is $0^{\circ} \mathrm{C}-2.8^{\circ} \mathrm{C}$; the hottest monthly average temperature is $11.5^{\circ} \mathrm{C}-18.2^{\circ} \mathrm{C}$; frost-free period is $180 \mathrm{~d}$; the average relative humidity is $60 \%-80 \%$. The soil is dominated by mountain brown soil and acidic brown soil. The main forest vegetation types in the mountain area are mountainous temperate dark coniferous forests, and Abies georgei var. Smithii is a kind of species, and there are Picea spp. Mixed forest and fir, Sabina saltuaria mixed forest, etc., and the dominant species of forest resources are the important species components of forest resources. Prior to this, the bryophytes in the Chitra Mountains have not been systematically investigated, and quantitative studies of species diversity have not yet been carried out. The study of bryophyte ecology is the process of understanding the bryophytes and their growing environment, and also provides the necessary reference for mankind to solve the ecological dilemma.

\section{Research Methods}

\subsection{Field Survey Method}

17 species of $10 \mathrm{~m} \times 10 \mathrm{~m}$ samples were selected according to the altitude gradient in the range of $3600-4700 \mathrm{~m}$ above sea level and at the elevation of the sunny slope. The number of trees and shrubs were measured and estimated its crown width, tree height and sample tree canopy closure, and then the sample is divided into $2 \mathrm{~m} \times 2 \mathrm{~m}$ sample. In each sample plot where there were bryophytes, $50 \mathrm{~cm} \times 50 \mathrm{~cm}$ small sample plots were set, the sample frame consisting of $1005 \mathrm{~cm} \times 5 \mathrm{~cm}$ grids was used for sampling, and the number of grid occupied by each kind of bryophyte was recorded as the coverage of a kind of moss in the sample plot [2]-[9].

\subsection{Data Analysis}

Using Excel 2010 and spss19.0 for all the data for statistical analysis and mapping.

\section{Results and Analysis}

\subsection{Composition and Characteristics of Mosses}

\subsubsection{Species Composition}

Table 1 is a statistical list of bryophytes in Sygara Mountain, Tibet. There were 136 species of bryophytes 28 families and 72 genera in the area. The species accounted for $10.71 \%, 4.17 \%$ and $2.21 \%$ of the total number of mosses, accounting for 133 species, accounting for $89.29 \%, 95.83 \%$ and $97.79 \%$ of the total number of mosses. 
Table 1. Bryophyte species statistics in Sygara Mountain in Tibet.

\begin{tabular}{ccccccc}
\hline & Families & $\begin{array}{c}\text { The } \\
\text { percentage } \\
\text { of families } \%\end{array}$ & genus & $\begin{array}{c}\text { The } \\
\text { percentage } \\
\text { of the genus\% }\end{array}$ & Specie & $\begin{array}{c}\text { The } \\
\text { percentage } \\
\text { of the specie \% }\end{array}$ \\
\hline Liverworts & 3 & 10.71 & 3 & 4.17 & 3 & 2.21 \\
Bryologr & 25 & 89.29 & 69 & 95.83 & 133 & 97.79 \\
Total & 28 & 100.00 & 72 & 100.00 & 136 & 100.00 \\
\hline
\end{tabular}

\subsubsection{Genotype and Species Composition of the Dominant Species}

From Table 2, it was found that the species of Bryaceae and Dicranaceae were the highest in the bryophytes of Sejila Mountain, And 10 genera and 15 species, followed by 11 species of Pottiaceae, 11 species of Brachytheciaceae, Grimmiaceae and Hypanaceae. The dominant family of bryophytes is in Sejila Mountain, Tibet. The six dominant families in the table contained 76 species and 76 species, accounting for only $21.43 \%$ of the total number of families, while the number and number of species accounted for $54.17 \%$ of the total and $55.88 \%$ of the total number of species, indicating that the above plants for the region The main group of bryophytes.

\subsection{The Life Type and Community Type of Bryophytes in the Season}

Life is the form of plant in the long-term adaptation to the comprehensive environmental conditions, in the appearance of similar forms (including plant morphology and living habits), and from these formal characteristics to illustrate the characteristics of the environment, which have similar environmental factors Adaptation of plants that make up a life type [10]. The moss plants of Sejila are divided into the following two types of life [11].

\subsubsection{Adnata}

Adnata can be divided into Epiphytia such as Herpetincuron toccoue (Sull. Et Lesq.) Card, Brachymenium ncpalen Hook. Epipctria, Ptychomitrium Linearifolium Reim., Gymnostomum calcareum Nees et Hornsch.; Epitcrra, such as Conocephalum conicum (L.) Dum.

\subsubsection{Radicantia}

Radicantia includes Hydro-radicantia, such as Brachythecium plumousum (Hedw.) B, SG, Mnium cuspidatum Hedw. Meso-radicantia, such as Entodon okamurae Broth, Thuidium cymbifolium (Doz. et Molk.) BSG, Pogonatum aloides (Hedw.) P. Beauv. [Ditrichum pallidum (Hedw.) Hamp.], Bryum agenteum Hedw.; Funaria hygrometrica Hedw.; Xero-radicantia, etc.: Pottiaceae, Bryaceae of some species.

\subsection{Bryophyte Community Type}

According to the growth matrices and ecological environment of bryophytes, the bryophyte community of Sygara can be divided into four groups: hydrophytia, 
Table 2. Bryophyte advantage of genera and species composition in Sygara Mountain in Tibet.

\begin{tabular}{cccccc}
\hline Number & Families & genus & $\begin{array}{c}\text { The percentage } \\
\text { of the genus\% }\end{array}$ & Specie & $\begin{array}{c}\text { The percentage } \\
\text { of the specie \% }\end{array}$ \\
\hline 1 & Brachytheciaceae & 4 & 5.56 & 9 & 6.62 \\
2 & Bryaceae & 4 & 5.56 & 23 & 16.91 \\
3 & Grimmiaceae & 5 & 6.94 & 9 & 6.62 \\
4 & Hypanaceae & 8 & 11.11 & 9 & 6.62 \\
5 & Pottiaceae & 8 & 11.11 & 11 & 8.09 \\
6 & Dicranaceae & 10 & 13.89 & 15 & 11.03 \\
& Total & 39 & 54.17 & 76 & 55.88 \\
\hline
\end{tabular}

geophytia, epixylophytia and Epicylophytia, according to Chen Bangjie's division of bryophyte communities in China [12]-[18]. Methods were investigated by field investigation and collection of typical community population [3]. The size of the sample was $50 \mathrm{~cm} \times 50 \mathrm{~cm}$. After identification and analysis, the dominant species of the community were the species of the community.

\subsubsection{Aquatic Community}

The aquatic bryophyte community refers to the bryophyte community that grows on the edge of the water and swamp, such as Mnium cuspidatum Com., Brachythecium plumosum Com.

\subsubsection{Native Communities}

The moss bryophyte community refers to the bryophyte community that is born on the ground soil or the thin soil. The native community is the main community type of bryophytes in the Sygara Mountains. On the subsoil, the common pure community has Funaria hygrometrica Com.; Bryum argenteum Com.; Ditrichum pallidum Com, The community (Pottiaceae Com.), et al. (Ditrichum pallidum-Brachytheciaceae Com.), (Thuidiaceae-Brachytheciaceae Com.) And other mixed communities Pogonatum aloides (Hedw.) P. Beauv.) are often formed on the shady sandy soil. In some weed-covered woodland soils, there are more species such as Entodonetum Com.; Mnium cuspidatum Com, et al. Then Weisia viridula Hedw. often mixed in other mosses in the composition of mixed communities.

\subsubsection{Shrubs Communities}

The bryophytes community refers to the bryophyte communities grown on trunks, trees and rotunders. There are many tall trees in the mountain, such as alpine oak, squalidae, arbuscularis, and sorghum, which provide a good habitat for the growth of bryophytes. The most common is the Entodon okamurae Com., Herpetineuron toccoae Com. Most of them form pure communities, sometimes intertwined with other mosses, such as often with the family of Thuidiaceae and Bryum argenteum. There are mossy families (Hypnaceae Com.), 
Leptohymenium macroalare Herz.Com.

\subsubsection{Quaternary Clay}

The bryophyte community refers to the bryophyte community on bare rock or rock surface. There are mainly species of Pottiaceae, such as Weisia viridula Hedw., Gymnostomum calcareum Nees et Hornsch, Ptychomitrium Linearifolium Reim.; [Herpetineuron toccoae (Sull. et Lesq.) Card.], and so on. Some species of Bryaceae and Pottiaceae are often used to form a mixed community.

It can be seen from Table 3 and Figure 1 that the bryophyte community type in the Sygara Mountain is the most dominant species, which is 25 species, accounting for $89.29 \%$ of the total species in the area, which is the dominant tree there are 18 species, accounting for $64.29 \%$ of the total species in the region. There are 13 species, accounting for $46.43 \%$ of the total species in the region. There are only 4 species of aquatic community type, accounting for the total species of the $14.29 \%$.

\section{Conclusion}

1) There are 136 species of bryophytes 28 families and 72 genera. The species accounted for $10.71 \%, 4.17 \%$ and $2.21 \%$ of the total number of mosses, accounting for 133 species, accounting for $89.29 \%, 95.83 \%$ and $97.79 \%$ of the total number

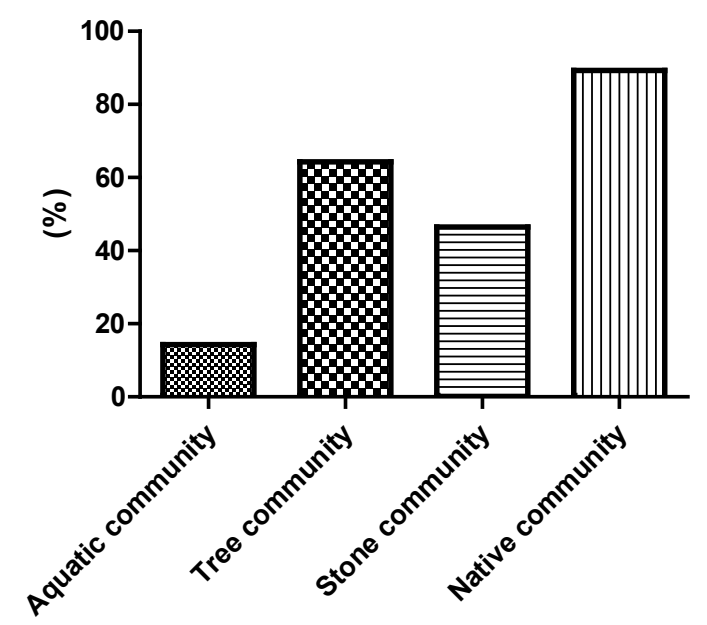

Figure 1. The percentage of the total number of families different community types (\%).

Table 3. Bryophyte community species composition in Sygara Mountain in Tibet.

\begin{tabular}{cccccc}
\hline \multirow{2}{*}{ Number } & Community & \multicolumn{3}{c}{ Specie } & \multirow{2}{*}{$\begin{array}{c}\text { The percentage } \\
\text { of families \% }\end{array}$} \\
\cline { 3 - 5 } & Liverworts & Bryologr & Total & 14.29 \\
\hline 1 & Aquatic community & 0 & 4 & 4 & 64.29 \\
3 & Tree community & 0 & 18 & 18 & 46.43 \\
4 & Stone community & 0 & 13 & 13 & 89.29 \\
\hline
\end{tabular}


of mosses. From the species point of view, some species are widely distributed and adaptable, such as some species of Brachytheciaceae, regardless of altitude. Habitat that is arid or damp, can survive and reproduce, and some species that have unique adaptability, such as: snake fur (Conocephalum conicum (L.) Dum.) only grow in the slightly higher temperature of the water or wetlands.

2) According to the number of bryophytes and species in the region, the six dominant families included 37 genera and 37 species. The number of subjects was only $21.43 \%$ of the total, while the number of species accounted for $54.17 \%$ of the total $55.88 \%$ of the total species, indicating the above-mentioned families of the bryophytes in the region of the main group. These dominant families include typical drought-tolerant families such as Pottiaceae and Bryaceae, as well as wet mosses such as Thuidiaceae and Brachytheciaceae. It is shown that the ecological community of bryophyte is rich and complex, which reflects the diversity and complexity of bryophyte habitat in this area.

3) From the perspective of life, the main type of Adnanta and Radicantia, From the point of community types, to the Geophytia as the main community, the most species, and Sygara Mountain virgin forest, shrub, Grassland and soil are closely related to the diversity of ecological environment; the second is the Epixycophytia and Petrophytia; the Epixycophytia are closely related to the richness of the woodland trees, and the Petrophytia are more exposed to the rocky and surface humidity. Hydrophytia are mainly distributed along streams and rivers, and its solid matrix is mostly water rock, floating in water or close to the stone surface, so its distribution is very limited and the species is the least.

4) Bryophytes rarely have a specific habitat, often with a wide ecological scale, and the same species can be distributed in the stone, soil and trunk, composed of different types of ecological communities, the formation of complex and diverse distribution.

5) The altitude, canopy closure and forest humidity, soil acidity, water content, richness of undergrowth trees are important environmental factors affecting the bryophyte diversity in the area. Therefore, the protection of bryophyte diversity should start from the protection of the forest, strengthen the protection of nature, the protection of the ecological environment of popular science propaganda, do forest fire prevention work, prohibit the chaos cutting and in the forest Daxing civil construction, reduce people and livestock on moss vegetation trampling for the survival of bryophytes to create good habitat conditions.

\section{Supported}

Supported by the National Natural Science Foundation of China (No.31640010), Tibet's research and development of characteristic agriculture and animal husbandry resources synergy innovation center-plateau ecological, Natural Science and Technology Foundation of the Tibet autonomous region (2016ZR-15-41), Tibet Agriculture and Animal Husbandry College Graduate Innovation Projects (YJS20160-5), The 2016 young university teachers innovation support program 
(QCZ2016-49), Tibet science and Technology Department-Office for the Institute of agriculture and animal husbandry School Fund (2016ZR-NY-03).

\section{References}

[1] Wang, Q., He, S.A. and Wu, P.C. (1999) The Role of Bryophytes in Biodiversity. Chinese Journal of Biodiversity, 7, 332-339.

[2] Gao, Q. (1994) Flora Bryophytorum Sinicorum. Science Press, Beijing.

[3] Gao, Q. (1996) Flora Bryophytorum Sinicorum. Science Press, Beijing.

[4] Wu, Z.Y. (2000) Flora of Yunnan. Science Press, Beijing.

[5] Li, X.J. (2000) Flora Bryophytorum Sinicorum. Science Press, Beijing.

[6] Li, X.J. (2002) Flora Bryophytorum Sinicorum. Science Press, Beijing.

[7] Li, X.J. (2006) Flora Bryophytorum Sinicorum. Science Press, Beijing.

[8] Wu, P.C. (2001) Flora Bryophytorum Sinicorum. Science Press, Beijing.

[9] Wu, P.C. and Jia, Y. (2005) Flora Bryophytorum Sinicorum. Science Press, Beijing.

[10] Yang, J. (1999) Botany Biology. Higher Education Press, Beijing, Springer-Verlag, Heidelberg.

[11] Yang, B.L. and Xiao, Y.S. (2003) The Resources of Bryophyte in Daweishan Nature Reserve. Journal of Southwest Forestry College, 23, 5-8.

[12] Yi, Y.J., Zhang, A.M., Wang, K.M., et al. (1998) On Study of Bryophytes of Konglin of Qufu City, Shandong Province. Journal of Qufu Normal University (Natural Science), 24, 90-95.

[13] Zhang, Y.M., Cao, T. and Pan, B.R. (2002) Study on Bryophytes and Their Distribution Patterns in Sangong River Watershed, Xinjiang. Arid Zone Research, 19, 39-43.

[14] Zhang, Z.H., Zhong, B.G., Wang, Z.H., et al. (1996) The Bryophytes Communities in Karst Caves of Huangguoshu. Guizhou Science, 14, 37-46.

[15] Zhang, T.H., Wang, Z.H., et al. (2013) Distribution of Bryophyte Communities form Karst Peak Cluster Rock Desertification in Valley of Siya River, Guizhou Province. Acta Botanica Boreali-Occidentalia Sinica, 33, 2104-2112.

[16] Li, X.N. (2016) Bryophyte Communities form Karst of Shibin, Guizhou Province. Agriculture of Jilin, 16, 56.

[17] Liu, R.X., Wang, Z.H. and Zhang, Z.H. (2009) Ecological Characteristics of Bryophyte Communities from Karst Rock Desertification Peak Cluster in Zhenfeng of Guizhou Province. Bulletin of Botanical Research, 29, 734-741.

[18] Ji, M.C. (1994) A Preliminary Study on Bryophyte Community of Yunju Mountain in Jiangxi. Jiangxi Science, 12, 100-104. 
Submit or recommend next manuscript to OALib Journal and we will provide best service for you:

- Publication frequency: Monthly

- 9 subject areas of science, technology and medicine

- Fair and rigorous peer-review system

- Fast publication process

- Article promotion in various social networking sites (LinkedIn, Facebook, Twitter, etc.)

- Maximum dissemination of your research work

Submit Your Paper Online: Click Here to Submit

Or Contact service@oalib.com 